\title{
Reproductive tactics used by the Lambari Astyanax aff. fasciatus in three water supply reservoirs in the same geographic region of the upper Iguaçu River
}

\author{
Juliano Pilotto Abelardino da Silva ${ }^{1}$, Adriane Esquivel Muelbert ${ }^{1}$, \\ Elton Celton de Oliveira ${ }^{1,2,3}$ and Luís Fernando Fávaro ${ }^{1,4}$
}

The species Astyanax aff. fasciatus was investigated as regards differences in reproductive tactics in three reservoirs with different ages (Iraí, Piraquara and Passaúna) located in the same geographic region. The biological material was obtained through monthly collections carried out from july/2006 to june/2007. The average value of the gonadosomatic index (GSI) in Passaúna reservoir was significantly higher in relation to the values obtained in the other reservoirs. Spawning was total in Iraí reservoir and partial in the others. Allometric growth of the species was negative in Iraí reservoir and positive in the others. The highest condition factor value was estimated in Iraí reservoir, followed by Piraquara and Passaúna reservoirs, respectively. Females predominated in all of the reservoirs during the study period. The sex ratio per length class showed, for the three reservoirs, the predominance of males in the smaller length classes. These results verified that the species uses distinct reproductive tactics in the analyzed reservoirs and that these tactics seem to reflect the degree of stabilization of each environment.

A espécie Astyanax aff. fasciatus foi investigada quanto a diferenças nas táticas reprodutivas em três reservatórios de diferentes idades (Iraí, Piraquara e Passaúna), localizados em uma mesma região geográfica. O material biológico foi obtido através de coletas mensais realizadas de julho/2006 a junho/2007. Evidenciou-se maior atividade reprodutiva nos períodos mais quentes do ano. $\mathrm{O}$ valor médio do IGS no reservatório do Passaúna apresentou-se significativamente maior em relação aos valores obtidos nos outros reservatórios. A desova foi caracterizada do tipo total no reservatório do Iraí e do tipo parcelada nos outros reservatórios. A espécie apresentou crescimento alométrico negativo no reservatório do Iraí e alométrico positivo nos reservatórios do Passaúna e Piraquara. O maior valor do fator de condição foi estimado no reservatório do Iraí, seguido pelos reservatórios do Piraquara e Passaúna, respectivamente. Durante o período de estudo as fêmeas predominaram sobre os machos em todos os reservatórios. A análise da proporção sexual por classe de comprimento evidenciou, para os três reservatórios, o predomínio de machos nas menores classes de comprimento. Através destes resultados constatou-se que a espécie utiliza táticas reprodutivas distintas para os reservatórios analisados e que estas táticas parecem refletir o grau de estabilização de cada ambiente.

Key words: Characidae, Succession, Spawning, Condition factors, Sex ratio.

\section{Introduction}

In general, fish reproduction consists of the phases of formation of the gametes, gonadal development, emptying of the gonads and subsequent fertilization. They are synchronized with the environmental alterations imposed by the seasons and, according to Jobling (1995) and Shiota (2003), the mechanisms that "trigger" reproduction in temperate and subtropical regions are related to variations in photoperiod and temperature.

Studies of the reproductive process in fishes supply results that allow inferences about the biology of the analyzed species and their relationship with the environment that they inhabit, making possible the evaluation of stocks, support and standardization of the fishery, and implementation of management plans when necessary (Dias et al., 1998). Works on reproduction are also used in the analysis of impacted areas, permitting the evaluation of the reproductive capacity of the species that suffer stress from anthropogenic environments (Carnelós \& Cecilio, 2002; Baylly et al., 2005; Wahbi \& El-Greisy, 2007). Thus, considering that reproductive success is fundamental to the perpetuation of fish species and the consequent viability of the populations, the evaluation and understanding of the reproduction of fishes in anthropogenic environments is of fundamental importance.

${ }^{1}$ Laboratório de Reprodução e Comunidade de Peixes, Universidade Federal do Paraná (UFPR).

${ }^{2}$ Pós-Graduando do Programa em Ecologia e Conservação, Universidade Federal do Paraná (UFPR).

${ }^{3}$ Universidade Tecnológica Federal do Paraná (UTFPR), Campus Campo Mourão. elton oliveirabio@yahoo.com.br ${ }^{4}$ (corresponding author) Departamento de Biologia Celular, Setor de Ciências Biológicas, Universidade Federal do Paraná (UFPR). Cx. Postal 19031, 81531-990 Curitiba, PR, Brazil. lufavaro@ufpr.br 
Among the various forms of anthropogenic action in aquatic environments, the construction of reservoirs has become more frequent due to the need for energy production or the supplying of water for human consumption, and their consequences affect strongly on fish populations (Agostinho et al., 2007).

The interruption in the hydrological dynamics of a river produces alterations in the physical and chemical attributes and results in biodiversity loss and in habitat reduction, which compromises the processes of population dispersion and persistence (Agostinho et al., 2005; Gubiani et al., 2007). Initially, after the implementation of a reservoir, a restructuration of the fish community will contribute to the reduction and/or the disappearance of species, including reophilic ones, in addition to probably producing an increase in species adapted to lentic environments (Agostinho et al., 2007), which present a high physiological tolerance and behavioral adaptability, leading to plasticity and, consequently, reproductive success (Gray et al., 2000; Lopes et al., 2000; Mammoliti, 2002; Dias et al., 2005).

Considering that the construction and the initial functioning of different reservoirs occur in distinct periods and ways, the reestablishment of an environmental balance should occur at different times. Thus, we believe that, in addition to the intrinsic characteristics, environments with different ages can present distinct processes of community restructuration, which produce differentiated pressures on the reproductive strategy of a certain species.

The species Astyanax aff.fasciatus (Cuvier, 1819) was used to test this prediction. Like other species of the genus, it has been documented as being highly dominant in dammed environments (Agostinho et al., 1997; Abilhoa, 2005), in addition to occupying the most diverse habitats in the hydrographic basins of Brazil (Garutti \& Britski, 2000). The wide food spectrum, optimized by the abundance of food available after damming, together with the production of numerous, small eggs that develop rapidly (Dias et al., 2005), are tactics that lead to their success at colonizing dammed environments.

Given the statements above, the present work sought to investigate differences in the reproductive tactics (the season reproductive, type of spawning, total and somatic condition factors, the sex ratio and the variation in the total length) of Astyanax aff. fasciatus in three reservoirs with different ages, located in the same geographic region, with the same photoperiod and temperature influences.

\section{Material and Methods}

\section{Identification of Astyanax aff. fasciatus}

In this work, all individuals were identified as the morphotype Astyanax sp. B, according to the available taxonomic characters indicated by Severi \& Cordeiro (1994), Garavello et al. (1997) and Ingenito et al. (2004). This specie, endemic to the Iguaçu River basin, belongs to the "Astyanax aff.fasciatus" species complex (Justi, 1993; Garutti \& Britski, 2000; Artoni et al., 2006), and was determined by the following diagnostic characters: 25 or more anal-fin rays, outer row of teeth on premaxilla with four teeth, posteroventral edge of third infraorbital almost contacting preopercle, two vertically elongate humeral spots (second one faint), and dorsal, anal and caudal fins red in life.

\section{Study area}

The three studied reservoirs (Iraí, Passaúna and Piraquara) are located in the hydrographic basin of the Iguaçu River (Paraná State, southern Brazil) (Fig. 1). The climate of the region is humid subtropical mesothermic, with mild summers and without a well-defined winter dry season (Maack, 1981). It presents a regular regime of rains over the year, occurring more intensely from January to February, with an average annual precipitation of $1354 \mathrm{~mm}$. The average minimum temperatures are between 12 and $13^{\circ} \mathrm{C}$ and the maximums between 20 and $22^{\circ} \mathrm{C}$ (Riffel, 2005).

According to data supplied by the Companhia de Saneamento do Estado do Paraná - SANEPAR (pers. comm. by Agenor Zarpelon, Coordenador de Produção de Água), Iraí reservoir was formed in 2001 and presents a flooded area of $14.7 \mathrm{~km}^{2}$, an average depth of $3.95 \mathrm{~m}$, a residence time of 1.02 years and has the coordinates UTM 22J 7.159.106 N and 683448 E (2540'26.54'S 49¹0'19.99”W). Passaúna reservoir, formed in 1989, flooded an area of $7.5 \mathrm{~km}^{2}$, possesses an average depth of $6.5 \mathrm{~m}$, a residence time of 0.8 years and has the coordinates UTM 22J 7.141.447 N and 638.220 E (25'50'18.27'’S 49³7'15.19'W). Piraquara reservoir was inaugurated in 1979. It flooded an area of $3.3 \mathrm{~km}^{2}$, possesses an average depth of $7 \mathrm{~m}$ and has the coordinates UTM 22J 7.143.051 N and 697.592 E (2549'01.56"S 4901'44.29'W).

\section{Collection and data analysis}

The obtaining of the biological material occurred through monthly collections (July 2006 to June 2007) that lasted $24 \mathrm{~h}$ in each of the studied reservoirs, using gillnets with different meshes.

The total length $(\mathrm{cm})$ and total weight $(\mathrm{g})$ of the previously identified specimens were recorded in the laboratory. After the ventral section of the specimens, sex and gonadal development were determined macroscopically according to the scale proposed by Vazzoler (1996) for females and by Santos et al. (2006) for males. The gonads were later removed and weighed $(\mathrm{g})$, and some were processed routinely for histological analysis.

Only the females had their gonads analyzed microscopically because, in addition to the production of the feminine gamete, the females are also responsible for incorporating nutrients in the oocytes to be used in the first phases of embryonic development, making the process of oogenesis very complex (Favaro et al., 2003). In addition, because the ovarian parenchyma structures are larger than the testicular ones, histological analysis makes it easier to follow the modifications in the development of the ovarian follicles, allowing precise characterization of the stages of ovarian development and the type of spawning. 


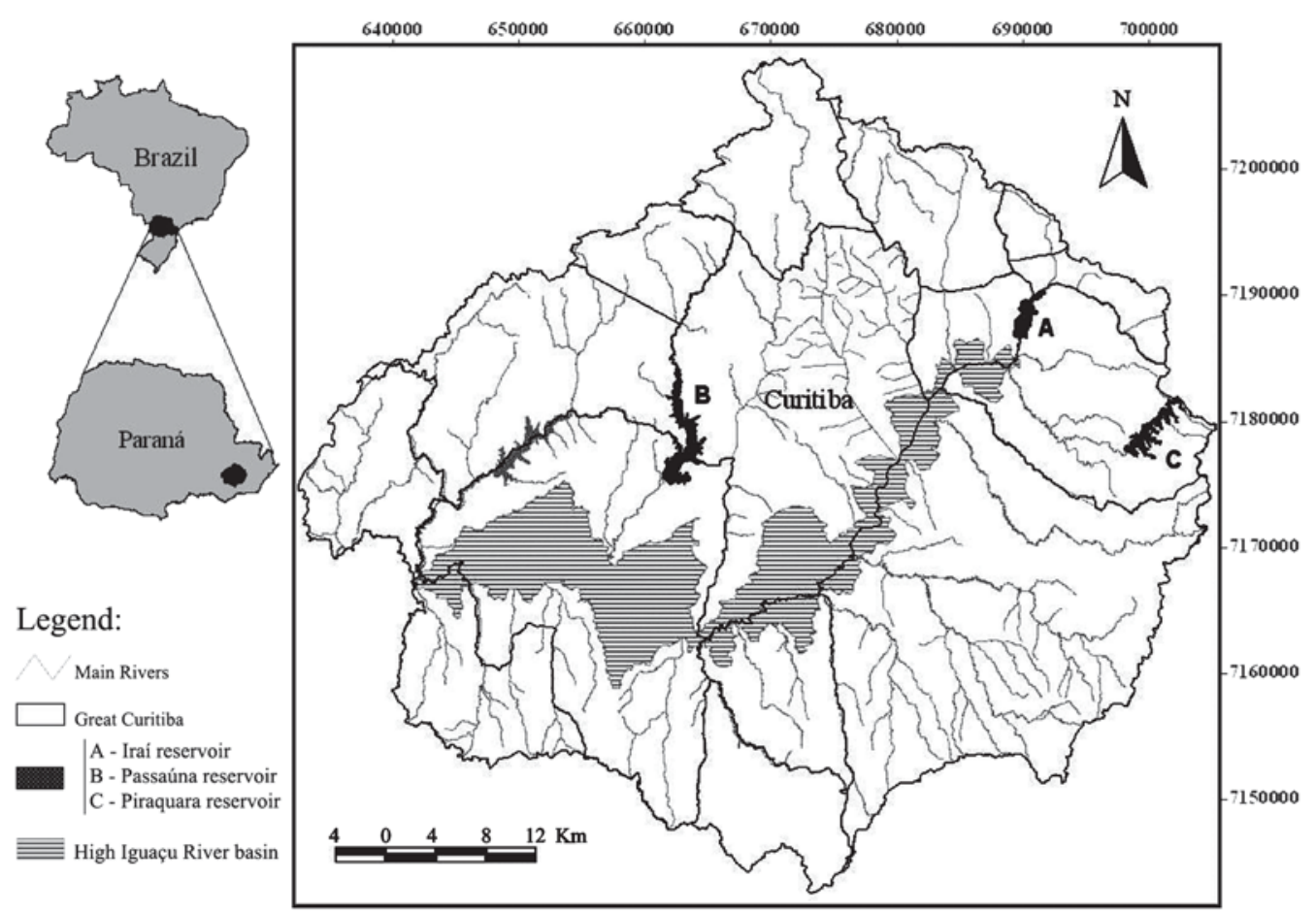

Fig. 1. Location of Iraí (A), Passaúna (B), and Piraquara (C) reservoirs in the region of the upper Iguaçu River basin, Paraná State, Brazil.

Different ovarian phases were characterized according to Favaro et al. $(2003,2005)$. The main microscopical characteristics in ovarian development are described below. Immature ovaries present oogonias and previtellogenic oocytes, organized in ovigerous lamellae. Ovaries in maturation contain previtellogenic and vitellogenic oocytes (with cytoplasmic vesicles and/or granules of yolk). Mature ovaries are characterized by the high frequency of oocytes full of yolk granules. Spawned ovaries present oogonias, previtellogenic oocytes and post ovulatory follicles, disorganized ovigerous lamellae and present conective tissue and evident vascularization. Besides that, the partially spawned ovary is characterized by the occurrence of ovarian follicles in different phases of development, presenting oocytes in vitellogenesis together with post ovulatory follicles.

In addition to qualitative analyses, quantitative indices were used to characterize the reproductive cycle of the species in each reservoir: percentage frequency distribution of the ovarian development stages, based on microscopic analyses of the ovaries; analysis of the maturation curve, made from the average monthly values of the gonadosomatic index (GSI) and the use of the total and somatic condition factors.

In order to relate energetic allocation with reproduction, representing the wellbeing of the females in each reservoir, the total $(\mathrm{K})$ and somatic $\left(\mathrm{K}^{\prime}\right)$ condition factors were obtained from the respective equations: $\mathrm{K}=\mathrm{Wt} / \mathrm{Lt}^{\mathrm{b}}$ and $\mathrm{K}{ }^{\prime}=\mathrm{Wc} / \mathrm{Lt}^{\mathrm{b}}$, where $\mathrm{Wt}=$ total weight, $\mathrm{Lt}=$ total length, $\mathrm{Wc}=$ weight of the body (total weight minus the weight of the ovary). The value of $b$, also used to determine the type of growth, was given through a minimum square method, using the expression $\mathrm{Wt}=\mathrm{a} \mathrm{Lt}{ }^{\mathrm{b}}$, where $a=$ intercept and $b=$ angular coefficient (Le Cren, 1951).

With the possibility of corroborating the total and somatic condition factor data, the variation in the total length of the specimens in each reservoir was verified through length classes established by the postulate of Sturges (Sokal \& Rohlf, 1981).

The sex ratio was determined for each analyzed reservoir through the absolute frequency of females and males per seasons and tested by the chi-square method $\left(\chi^{2}\right)$, according to Vazzoler (1996). The sex ratio was also analyzed per length class, determined by the postulate of Sturges (Sokal \& Rolf, 1981).

The assumption of normal distribution of the residuals and homogeneity of the variances, were checked using the Kolmogorov-Smirnov and Levene tests, respectively. The Student t-test for heterogeneous variances (Zar, 1999) was used in order to compare the GSI and condition factor data (between the studied reservoirs), since the data had a normal distribution and heterogeneous variances. The violation of the assumptions of homogeneity of the variances between the treatments made the use of an analysis of parametric variance (ANOVA) impossible, since, according to Zimmerman (2006), both ANOVA and the Kruskal-Wallis test (nonparametric analysis of variance) are sensitive to heterogeneous variances. The GSI values of only mature females were tested between the three reservoirs using an ANOVA, since, in this case, the assumptions of normality and homogeneity of the variances had been reached. Transformations using square roots were carried out in the tests to compare the GSI, the condition factor and the total length of the populations between the reservoirs (respecting the conditions for using the above-described tests). 
Voucher specimens were deposited in the fish collection at the Museu de História Natural do Capão da Imbuia (MHNCI) (Astyanax aff.fasciatus: MHNCI 9213, five specimens).

\section{Results}

Of the total of 720 specimens of Astyanax aff. fasciatus, 247 individuals were captured in Iraí reservoir ( 171 females, 67 males, four hermaphrodites and five unidentified), 275 in Passaúna reservoir (151 females and 124 males) and 198 in Piraquara reservoir (126 females, 68 males and four specimens with unidentified gonads).

The analysis of the reproductive process in each reservoir, through the monthly percentage frequency distribution of the ovarian stages and the maturation curve, showed high reproductive activity in the hotter periods of the year, i.e., spring and summer.

The high frequencies of mature females in Iraí reservoir occurred between August and December, corroborating the high GSI averages verified from August to November. Mature ovaries in Passaúna reservoir were observed with great frequency from October to February, coinciding with the period of high GSI averages. Mature females in Piraquara reservoir were observed during every sampling month except June, which represented $100 \%$ of spent females. High GSI averages were observed from September to March, identifying the season of high reproductive activity (Fig. 2).

The average value of the GSI in Passaúna reservoir (2.42), obtained for all stages of ovarian development during the study period, was significantly higher in relation to the values obtained in Iraí (1.61) and Piraquara (1.54) reservoirs (Iraí x Passaúna: $\mathrm{t}_{208}=-5.19, \mathrm{df}=206, \mathrm{p}<0.05$; Iraí $\mathrm{x}$ Piraquara: $\mathrm{t}_{208}=$ $0.62, \mathrm{df}=206, \mathrm{p}>0.05$; Passaúna $\mathrm{x}$ Piraquara: $\mathrm{t}_{208}=-4.95, \mathrm{df}=$ $206, \mathrm{p}<0.05)$.

The mature females of Passaúna reservoir presented a significantly higher GSI average in relation to the other reservoirs; whereas Iraí and Piraquara reservoirs presented similar averages $\left(\mathrm{F}_{2 ; 170}=49.88, \mathrm{p}<0.05\right)$.

Total spawning in Iraí reservoir was characterized through histological analysis, since partially spawned specimens were not observed. The occurrence of partially spawned females allowed the characterization of partial spawning in Passaúna and Piraquara reservoirs (Fig. 3). The partially spawned ovary, when observed through histology, presented ovarian follicles previtellogenic, in vitellogenesis, mature and empty, with absent or few atresic follicles.

The monthly values of the condition factors $\mathrm{K}$ and $\mathrm{K}$ ' fell during the reproductive period of Iraí reservoir, and later rose in the post-spawning period. A large difference between $\mathrm{K}$ and $\mathrm{K}$ ' was observed from August to December, reflecting great gonadal development. As regards Passaúna and Piraquara reservoirs, the average values of the condition factors $\mathrm{K}$ and $\mathrm{K}$ 'varied little over the whole year, with the largest differences occurring in the reproductive period (Fig. 4).

Astyanax aff. fasciatus presented negative allometric growth $(b=2.4)$ in Iraí reservoir, characterized by a large increase in length in relation to weight. The species presented positive allometric growth $(b=3.3$ and 3.2$)$ in Passaúna and Piraquara reservoirs, respectively, and was characterized by a large increase in weight in relation to length.

Comparison of the females of the three reservoirs in relation to the condition factor indicated significant difference between them, with the highest value from Iraí $(0.228)$, followed by Piraquara (0.094) and Passaúna (0.086), (Iraí x Passaúna: $\mathrm{t}_{263}=$ 144.27, $\mathrm{df}=261, \mathrm{p}<0.05$; Iraí $\mathrm{x}$ Piraquara: $\mathrm{t}_{241}=121.68, \mathrm{df}=239$, $\mathrm{p}<0.05$; Passaúna x Piraquara: $\mathrm{t}_{230}=-16.13, \mathrm{df}=228, \mathrm{p}<0.05$ ).

The analysis of total length, carried out using nine length classes, characterized the population of Iraí reservoir as smallsized, with the largest individual having a total length of 12.6 $\mathrm{cm}$. The population of Astyanax aff. fasciatus of Passaúna reservoir was represented by large-sized specimens, predominating in the large length classes (between 12.4 and $17.3 \mathrm{~cm}$ ) (Fig. 5). The population of Iraí reservoir was statistically verified to be small-sized, that of Piraquara intermediate-sized and that of Passaúna large-sized (Iraí x Passaúna: $\mathrm{t}_{263}=-12.22$, $\mathrm{df}=261, \mathrm{p}<0.05$; Iraí $\mathrm{x}$ Piraquara: $\mathrm{t}_{241}=-4.18, \mathrm{df}=239, \mathrm{p}<0.05$; Passaúna $x$ Piraquara: $\left.\mathrm{t}_{230}=8.42, \mathrm{df}=228, \mathrm{p}<0.05\right)$.

The females of Astyanax aff. fasciatus of Iraí reservoir predominated in number of individuals, with a significant predomination in summer and autumn. The females predominated in Passaúna reservoir, with no evidence of significant difference in the sex ratio over the year. Significant difference in the sex ratio was observed in winter in Piraquara reservoir, with females predominating (Table 1). The analysis of the sex ratio per length class showed, for the three reservoirs, the predominance of males in the small length classes and females in the large (Table 2).

\section{Discussion}

Reproductive tactics depend on the interactions between the environment and the genetic, physiological, behavioral and ecological response of individuals attempting to manifest a reproductive strategy (Potts \& Wootton, 1984). Thus, the temporal and spatial variations shown in the reproductive tactics used by the assemblages of Astyanax aff. fasciatus in the different reservoirs are probably due the succession process of the community, which is directly related to the different ages of the reservoirs and reflects differences in geomorphology (form, size and depth) that provide distinct biotic and abiotic conditions.

The community succession process consists of the qualitative and quantitative change of species that compose

Table 1. Seasonal distribution of the sex ratio of Astyanax aff. fasciatus in Iraí, Passaúna and Piraquara reservoirs. F = Females; $\mathrm{M}=$ Males. ${ }^{*}$ Significant values $(\mathrm{p}<0.05)$.

\begin{tabular}{lccccccccc}
\hline \multirow{2}{*}{ Season } & \multicolumn{4}{c}{ Iraí } & \multicolumn{3}{c}{ Passaúna } & \multicolumn{3}{c}{ Piraquara } \\
\cline { 2 - 10 } & $\mathrm{F}$ & $\mathrm{M}$ & $\chi^{2}$ & $\mathrm{~F}$ & $\mathrm{M}$ & $\chi^{2}$ & $\mathrm{~F}$ & $\mathrm{M}$ & $\chi^{2}$ \\
\hline Spring & 32 & 22 & 1.85 & 34 & 32 & 0.06 & 60 & 46 & 1.85 \\
Summer & 51 & 6 & $35.53^{*}$ & 49 & 35 & 2.33 & 10 & 4 & 2.57 \\
Autunm & 48 & 24 & $8.00^{*}$ & 24 & 36 & 2.40 & 4 & 1 & 1.80 \\
Winter & 6 & 8 & 0.29 & 19 & 15 & 0.47 & 30 & 16 & $4.26^{*}$ \\
Total & 137 & 60 & & 126 & 118 & & 104 & 67 & \\
\hline
\end{tabular}



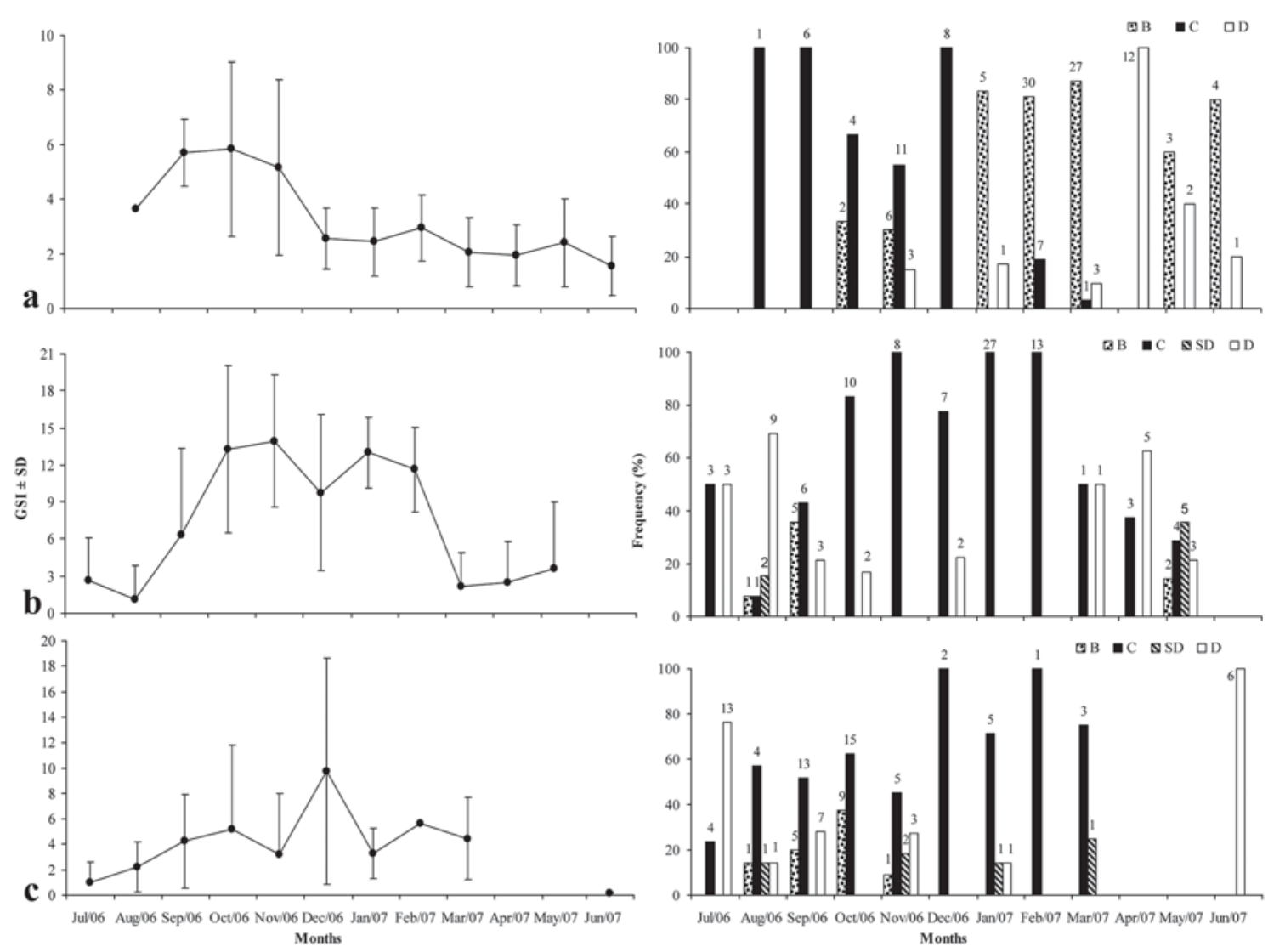

Fig. 2. Maturation curve and monthly distribution of the percentage frequency of the stages of ovarian development of Astyanax aff. fasciatus females in the Iraí (a), Passaúna (b), and Piraquara (c) reservoirs. The numbers indicated above the bars refer to absolute frequency and the letters indicated gonadal development: $\mathrm{B}=$ maturation, $\mathrm{C}=$ mature, $\mathrm{SD}=$ partially spawned, and $\mathrm{D}=\mathrm{spawned}$.

the community and occurs due to environmental stress (e.g., reservoir formation) until the environment stabilizes. According to Begon et al. (2007), Gomiero \& Braga (2007) and Baylly et al. (2005), colonizer species with an r-strategist tendency and high food and physiological plasticity, associated with high reproductive capacity, initially dominate new environments with fluctuating environmental conditions. The same authors relate that later, specialist species, which may be competitively superior to colonizer species, in an attempt to also use the environment, trigger an interspecific competition for resources.

Through the negative relationship between species richness and reservoir age, described in a study carried out in reservoirs in the upper Paraná River region (Agostinho et al., 1995), corroborated by collections carried out in 2001 (Agostinho et al., 2007) in the same reservoirs analyzed in the present study, it is evident that the succession processes are in different phases.

Considering Astyanax aff. fasciatus to be a colonizer species and Passaúna and Piraquara reservoirs to be older (Agostinho et al., 2007), with more advanced succession processes in relation to Iraí reservoir, we should consider that the pressures on the populations of the aforesaid species are different in type and intensity, making possible variations in the reproductive period, spawning type, GSI values, condition factor, total length and sex ratio. According to
Vazzoler (1996), the variations in the reproductive tactics reflect the strategy used by these populations to keep themselves in the system.

The well-defined reproductive period and the total spawning observed in Iraí reservoir are possibly reproductive tactics used by the species at the start of the succession process, when there are still few specialist species and the fluctuations of the local abiotic factors are supported by the physiological characteristics, determining the efficacy of the reproductive tactics used.

The observation of mature and spent females caught over the year and partial spawning, verified in Passaúna and Piraquara

Table 2. Distribution of the sex ratio per length classes of Astyanax aff. fasciatus in Iraí, Passaúna and Piraquara reservoirs. $\mathrm{F}=$ Females; $\mathrm{M}=$ Males. ${ }^{*}$ Significant values $(\mathrm{p}<0.05)$.

\begin{tabular}{cccccccccccc}
\hline \multicolumn{3}{c}{ Iraí } & \multicolumn{4}{c}{ Passaúna } & \multicolumn{4}{c}{ Piraquara } \\
\hline Classes & $\mathrm{F}$ & $\mathrm{M}$ & $\chi^{2}$ & Classes & $\mathrm{F}$ & $\mathrm{M}$ & $\chi^{2}$ & Classes & $\mathrm{F}$ & $\mathrm{M}$ & $\chi^{2}$ \\
\hline $8.4-8.8$ & 1 & 3 & 1.00 & $8.9-9.7$ & 5 & 18 & $7.35^{*}$ & $9.3-10.2$ & 19 & 36 & $5.25 *$ \\
$8.9-9.3$ & 6 & 4 & 0.40 & $9.8-10.6$ & 19 & 28 & 1.72 & $10.3-11.2$ & 37 & 24 & 2.77 \\
$9.4-9.8$ & 25 & 15 & 2.50 & $10.7-11.5$ & 17 & 24 & 1.20 & $11.3-12.2$ & 39 & 4 & $28.49 *$ \\
$9.9-10.3$ & 21 & 15 & 1.00 & $11.6-12.4$ & 9 & 11 & 0.20 & $12.3-13.2$ & 3 & 1 & 1.00 \\
$10.4-10.8$ & 21 & 8 & $5.83 *$ & $12.5-13.3$ & 0 & 7 & $7.00 *$ & $13.3-14.2$ & 0 & 0 & \\
$10.9-11.3$ & 25 & 13 & 3.79 & $13.4-14.2$ & 9 & 19 & 3.57 & $14.3-15.2$ & 2 & 0 & 2.00 \\
11.411 .8 & 23 & 1 & $20.17 *$ & $14.3-15.1$ & 46 & 10 & $23.14 *$ & $15.3-16.2$ & 3 & 0 & 3.00 \\
$11.9-12.3$ & 13 & 1 & $10.29 *$ & $15.2-16.0$ & 20 & 0 & $20.00 *$ & $16.3-17.3$ & 1 & 1 & 0.00 \\
$12.4-12.9$ & 2 & 0 & 2.00 & $16.1-17$ & 1 & 1 & 0.00 & & & & \\
\hline
\end{tabular}



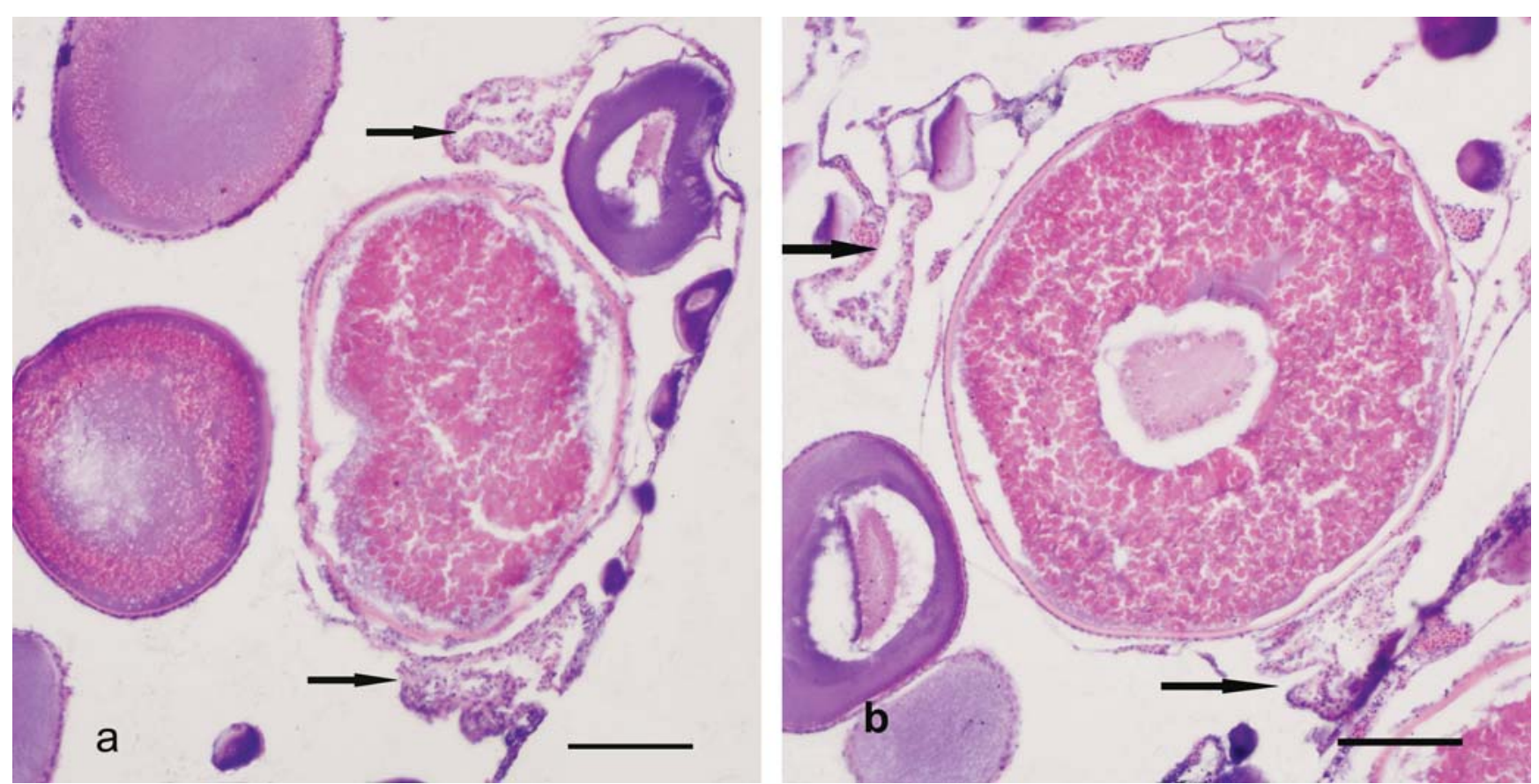

Fig. 3. Histological slides of partially spawned ovary of Astyanax aff. fasciatus of Passaúna and Piraquara reservoirs, HE staining. Post ovulatory follicles (arrow). Scale bar $=80 \mu \mathrm{m}$.

reservoirs, demonstrate that Astyanax aff. fasciatus allocates energy to intermittent reproduction, attaining reproductive success in environments that present specialist species and resources which are now limited because of a more advanced succession process in relation to Iraí reservoir. Our data corroborate the results obtained by Mazzoni et al. (2005), Abilhoa \& Agostinho (2007) and Santos \& Novaes (2008), who also characterized long reproductive periods for other Astyanax species in natural environments containing specialist species.

The difference in the type of growth presented by the species in the three reservoirs reflects distinct manners of allocated energetic resource use, with the objective of obtaining a better condition of permanence in the different environments, which exert different types and intensities of pressure. The large increase in weight may be associated with a long reproductive period and partial spawning, as shown in Passaúna and Piraquara reservoirs.

During the months that precede the reproductive period, an investment in tissue accumulation is necessary to give support to the gonadal cycle (Abelha \& Goulart, 2008). The destination of somatic energy to the gonads during gonadal development is necessary to carry out the reproductive process. The stress caused by spawning generally suggests a period of lesser well being for the species in the environment, probably caused by the use of previously stored energy. Conditions improve in the post-spawning period. These differences were more significant in Iraí reservoir, where the species presented a well-defined reproductive period and total spawning. The variation in the condition factor over the months was less evident in Passaúna and Piraquara reservoirs, where the species presented long reproductive periods and partial spawning. Our data corroborate the accounts of Barbieri et al. (1996) and Gurgel
(2004), who showed (for Astyanax fasciatus) high condition factor values in the pre- and post-spawning period.

The fact that the primary productivity of a reservoir, among other aspects, is a reflection of its age, corroborates the high condition factor values in Iraí reservoir. The more recent the reservoir, the greater the production on every trophic level. This results from a large nutrient input made available by the flooding of the surrounding area (Agostinho et al., 2007). In addition, the low average depth of Iraí reservoir and the long residence time of the waters favor the development of large populations of phytoplankton. Thus, the food plasticity developed by Astyanax aff. fasciatus benefits the occupation of new environments, and maintains the population in favorable conditions.

The difference observed in relation to the total length of the analyzed populations may also be explained by the community succession process. Considering Passaúna and Piraquara reservoirs to be older, with more advanced succession processes (in relation to Iraí), the greater total length of the specimens may be a strategy for these populations to keep themselves in the system, even in the presence of specialist species. According to Shine (1990), the larger body size of the females favors an increase in fertility, and collaborates in the reproductive success of the species. Thus, we suggest that part of the allocated resources is destined for growth and part for reproduction over the year. On the other hand, in Iraí reservoir, the most recent reservoir and where the specimens present the smallest total lengths, the population destines most of the resources to the reproductive process, with no necessity of a high investment in growth, possibly because the succession is found in an initial stage, not yet allowing the establishment of specialist species, which may be superiorly competitive. 
The sex ratio, analyzed in this study because it is considered an important reproductive tactic, demonstrated a pattern of predominance of females for most of the year in every reservoir, corroborating the results found by Abilhoa \& Agostinho (2007), who analyzed the population of Astyanax sp. B in marginal lagoons of the upper Iguaçu River. Studies carried out by Abelha \& Goulart (2008) and by Santos \& Novaes (2008) for Astyanax altiparanae and Astyanax sp. B, respectively, recorded the prevalence of females (possibly a

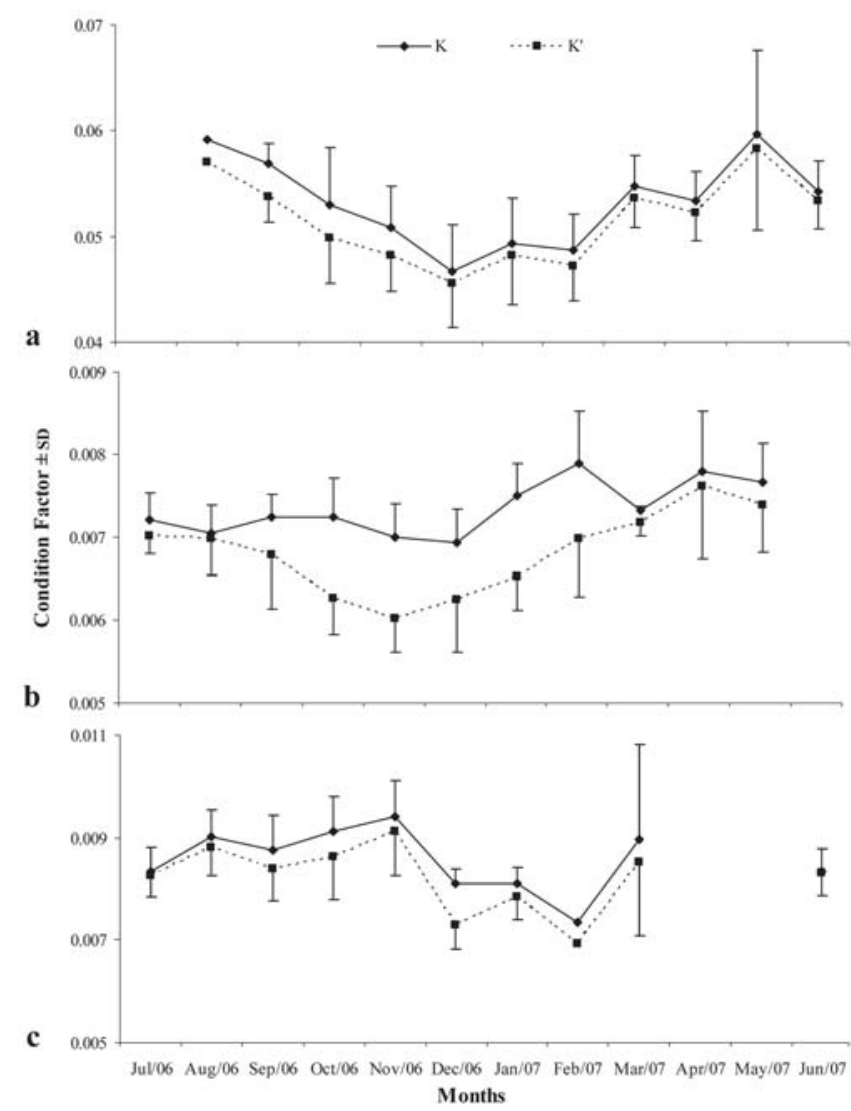

Fig. 4. Monthly distribution of the total (K) and somatic (K') condition factors of Astyanax aff. fasciatus in Iraí (a), Passaúna (b), and Piraquara (c) reservoirs. $\mathrm{K}=$ continuous line, $\mathrm{K}^{\prime}=$ dotted line.

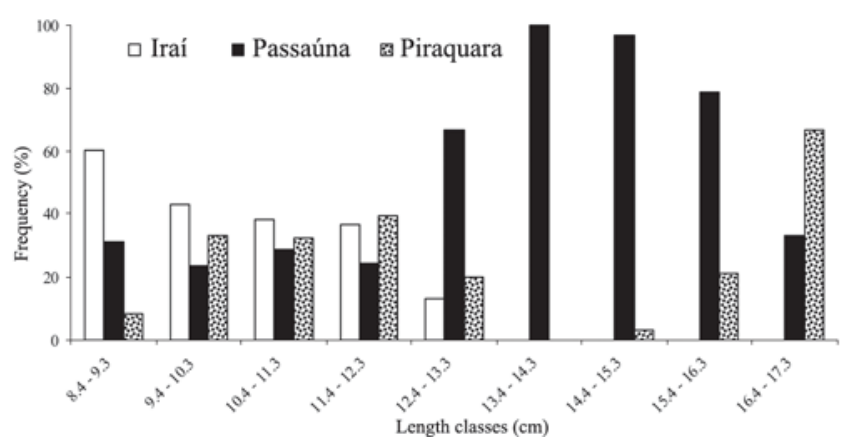

Fig. 5. Distribution of the percentage frequency in length classes of Astyanax aff. fasciatus individuals of Iraí, Passaúna and Piraquara reservoirs. characteristic of the Astyanax group). In addition, the differentiated growth rates, the high mortality of males, the high longevity of females or even the susceptibility to the fishing equipment used may explain the predominance of females (Abilhoa \& Agostinho, 2007). It could even be associated with the abundance of available food (a response of the species to this condition) (Lopes et al., 2000).

According to the results obtained in the present study, Astyanax aff. fasciatus presented distinct reproductive tactics in the analyzed reservoirs (located in the same geographic area and belonging to the same hydrographic basin). The reproductive tactics used by the species seem to reflect different phases of the succession process and the degree of stabilization of the environments, thus demonstrating that the age of the reservoirs influences the restructuration of the fish community and the abiotic factors at each site. These results contribute to a better understanding of the dynamics of the reservoirs over time (years) and to possible management actions in these environments.

\section{Acknowledgements}

The authors thank the Fundação Araucária de Apoio ao Desenvolvimento Científico e Tecnológico do Paraná, the Conselho Nacional de Desenvolvimento Científico e Tecnológico (CNPq) and the Coordenação de Aperfeiçoamento de Pessoal de Nível Superior (CAPES) for the concession of scholarships (Bolsas de Iniciação Científica e de Doutorado); Vinícius Abilhoa, Leonardo Pussieldi Bastos and Letícia de Lima for obtaining biological material, and André Segura Tomasi for map development.

\section{Literature Cited}

Abelha, M. C. F. \& E. Goulart. 2008. Population structure, condition factor and reproductive period of Astyanax paranae (Eigenmann, 1914) (Osteichthyes: Characidae) in a small and old brazilian reservoir. Brazilian Archives of Biology and Technology, 51(3): 503-512.

Abilhoa, V. Ictiofauna. 2005. Pp. 435-456. In: Andreoli, C. V. \& C. Carneiro. Gestão integrada de Mananciais de Abastecimento Eutrofizados. Curitiba, Ed. Gráfica Capital Ltda, 500p.

Abilhoa, V. \& A. A. Agostinho. 2007. Aspectos biológicos de duas espécies de Astyanax (Teleostei, Characidae) em lagoas marginais do alto rio Iguaçu, Paraná, Brasil. Estudos de Biologia, 29(66): 23-32.

Agostinho, A. A., L. M. Bini \& L. C. Gomes. 1997. Ecologia de comunidades de influência do reservatório de Segredo. Pp. 97-111. In: Agostinho, A. A. \& L. C. Gomes (Eds.). Reservatório de Segredo: bases ecológicas para o manejo. Maringá, Eduem, 387p.

Agostinho, A. A., L. C. Gomes \& F. M. Pelicice. 2007. Ecologia e Manejo de Recursos Pesqueiros em Reservatórios do Brasil. Eduem, Maringá, 501p.

Agostinho, A. A., S. M. Thomaz \& L. C. Gomes. 2005. Conservation of the Biodiversity of Brazil's Inland Waters. Conservation Biology, 19(3): 646-652.

Agostinho, A. A., A. E. A. M. Vazzoler \& S. M. Thomaz .1995. The high River Paraná Basin: limnological and ichthyological aspects. Pp. 59-103. In: Tundisi, J. G., C. E. M. Bicudo \& T. MatsumuraTundisi (Eds.). Limnology in Brazil. ABC/SBL, São Paulo, $384 \mathrm{p}$. 
Artoni, R. F., O. A. Shibatta, M. C. Gross, C. H. Schneider, M. C. Almeida, M. R. Vicari \& L. A. C. Bertollo. 2006. Astyanax aff. fasciatus Curvier, 1819 (Teleostei; Characidae): evidences of a species complex in the upper rio Tibagi basin (Paraná, Brazil). Neotropical Ichtyology, 4(2): 197-202.

Barbieri, G., S. Hartz \& J. R. Verani. 1996. O fator de condição e índice hepatossomático como indicadores do período de desova de Astyanax fasciatus Cuvier, 1819, da Represa do Lobo, São Paulo (Osteichthyes, Characidae). Iheringia, Série Zoologia, (81): 97-100.

Baylly, D., A. A. Agostinho, H. I. Suzuki \& E. A. Luiz. 2005. Características reprodutivas de espécies de Astyanax e sucesso na colonização de reservatórios do rio Iguaçu, PR. Pp. 243-252 In: Rodrigues, L., S. M. Thomaz, A. A. Agostinho \& L. C. Gomes (Org.). Biocenoses em Reservatórios: padrões espaciais e temporais. São Carlos, Editora RiMa, 333p.

Begon, M., C. R. Townsend \& J. L. Harper. 2007. Ecologia: de indivíduos a ecossistemas. $4^{\mathrm{a}}$ edição, Artmed, 752p.

Carnelós, R. C. \& E. B. Cecilio. 2002. Reproductive strategies of Plagioscion squamosissimus Heckel, 1840 (Osteichthyes Sciaenidae) in the Itaipu Reservoir, Brazil. Brazilian Archives of Biology and Technology, 45(3): 317-324

Dias, R. M., R. R. A. Bailly, H. I. Suzuki \& A. A. Agostinho. 2005. Colonization of the Corumbá Reservoir (Corumbá River, Paraná River Basin, Goiás State, Brazil) by the "lambari" Astyanax altiparanae (Tetragonopterinae; Characidae). Brazilian Archives of Biology and Technology, 48(3): 467-476.

Dias, J. F., E. Peres-Rio, P. T. C. Chaves \& C. L. D. B. RossiWongtschowski. 1998. Análise macroscópica dos ovários de teleósteos: problemas de classificação e recomendações de procedimentos. Revista Brasileira de Biologia, 58(1): 55-69.

Fávaro, L. F., F. A. Frehse, R. N. Oliveira \& R. Schwarz Junior. 2005. Reprodução do bagre amarelo, Cathorops spixii (Agassiz) (Siluriformes, Ariidae), da Baía de Pinheiros, região estuarina do litoral do Paraná, Brasil. Revista Brasileira de Zoologia, 22(4): 1022-1029.

Fávaro, L. F., S. C. G. Lopes \& H. L. Spach. 2003. Reprodução do peixe-rei, Atherinella brasiliensis (Quoy \& Gaimard) (Atheriniformes, Atherinidae), em uma planície de maré adjacente à gamboa do Baguaçu, Baía de Paranaguá, Paraná, Brasil. Revista Brasileira de Zoologia, 20(3): 501-506.

Garavello, J. C., C. S. Pavanelli \& H. I. Suzuki. 1997. Caracterização da Ictiofauna do rio Iguaçu. Pp. 61-84. In: Agostinho, A. A. \& L. C. Gomes (Eds.). Reservatório de Segredo: bases ecológicas para o manejo. Maringá. Eduem, 387p.

Garutti, V. \& H. A. Britski. 2000. Descrição de uma espécie nova de Astyanax (Teleostei: Characidae) da bacia do alto rio Paraná e considerações sobre as demais espécies do gênero na bacia. Comunicações do Museu de Ciências e Tecnologia da PUCRS, Série Zoologia, 13: 65-88.

Gomiero, L. M. \& F. M. S. Braga. 2007. Reproduction of a fish assemblage in the state of São Paulo, southestern Brazil. Brazilian Journal of Biology, 67(2): 283-292.

Gray, S. C., S. S. Silva, B. A. Ingram \& G. J. Gooley. 2000. Effects of river impoundment on body condition and reproductive performance of the Australian native fish, Macquarie perch (Macquaria australasica). Lakes \& Reservoirs: Research and Management, 5: 281-291.

Gubiani,É.A.,L.C.Gomes,A.A.Agostinho \&E.K. Okada. 2007.Persistence of fish populations in the upper Paraná River: effects of water regulation by dams. Ecology of Freshwater Fish, 16(2): 191-197.

Gurgel, H. C. B. 2004. Estrutura populacional e época de reprodução de Astyanax fasciatus (Cuvier) (Characidae, Tetragonopterinae) do Rio Ceará Mirim, Poço Branco, Rio Grande do Norte, Brasil. Revista Brasileira de Zoologia, 21(1): 131-135.
Ingenito, L. F. S., L. F. Duboc \& V. Abilhoa. 2004. Contribuição ao conhecimento da ictiofauna da bacia do alto rio Iguaçu, Paraná, Brasil. Arquivos de Ciências Veterinárias e Zoologia da UNIPAR, 7: 23-36.

Jobling, M. 1995. Environmental Biology of Fishes. London, Chapman \& Hall, 455p.

Justi, A. J. 1993. Caracterização cariotípica de populações de Astyanax fasciatus (Cuvier, 1819) Pisces, Characidae, em três bacias hidrográficas. Unpublished M.Sc. Thesis. Universidade Federal de São Carlos, São Carlos, 83p.

Le Cren, E. D. 1951. The lenght-weight relationshipand seasonal cycle in gonad and conditions in the perch Perca fluviatilis. Journal Animal Ecology, 20(2): 201-219.

Lopes, C. A., E. Benedito-Cecilio \& A. A. Agostinho. 2000. The reproductive strategy of Leporinus friderici (Characiformes, Anostomidae) in the Paraná river basin: the effect of reservoirs. Revista Brasileira de Biologia, 60(2): 255-266.

Maack, R. 1981. Geografia física do Estado do Paraná. Rio de Janeiro, José Olímpio Editora, 450p.

Mammoliti, C. S. 2002. The effects of small watershed impoundments on native stream fishes: a focus on the Topeka Shiner and Hornyhead Chub. Transactions of the Kansas Academy of Science, 105(3/4): 219-231.

Mazzoni, R., R. S. Mendonça \& E. P. Caramaschi. 2005. Reproductive Biology of Astyanax janeiroensis (Osteichthyes, Characidae) from the Ubatiba River, Maricá, RJ, Brazil. Brazilian Journal of Biology, 65(4): 643-649.

Potts, G. W. \& R. J. Wootton. 1984. Fish reproduction: Strategies and Tactics. London, Academic Press, 410p.

Riffel, S. B. 2005. Curva hipsométrica no mapeamento de Paleosuperfícies: abordagem quantitativa. Unpublished Ph.D Dissertation, Universidade Federal do Paraná, 76p.

Santos, R. N., C. C. Andrade, L. N. Santos, A. F. G. N. Santos \& F. G. Araújo. 2006. Testicular maturation of Oligosarcus hepsetus (Cuvier) (Actinopterygii, Characidae) in a brazilian tropical reservoir. Brazilian Journal of Biology, 66(1A): 143-150.

Santos, A. C. A. \& J. L. C. Novaes. 2008. Population Structure of two Astyanax Baird \& Girard, 1854 (Teleostei, Characidae) species from Upper Paraguaçu River. Brazilian Archives of Biology and Technology, 51(1): 105-112.

Severi, W. \& A. A. M. Cordeiro. 1994. Catálogo de peixes da bacia do rio Iguaçu. Curitiba, IAP/GTZ, 118p.

Shine, R. 1990. Proximate determinants of sexual differences in body size. American Naturalist, 135: 278-283.

Shiota, T., A. Ishimatsu \& K. Soyano. 2003. Effects of temperature on gonadal development of mudskipper (Periophthalmus modestus). Fish Physiology and Biochemistry, Holanda, 28: 445-446.

Sokal, R. R. \& F. J. Rohlf. 1981. Biometry. New York, W. H. Freeman, 859p.

Vazzoler, A. E. M. M. 1996. Biologia da reprodução de peixes teleósteos: teoria e prática. Maringá, Eduem, 169p.

Wahb, O. M. \& Z. A. El-Greisy. (2007). Comperative impact of different waste sources on the reproductive parameters and histology of gonads, liver and pituitary gland of Siganus rivaltus. Journal of Applied Sciences Research, 3(3): 236-244.

Zar, J. H. 1999. Biostatistical Analysis. $4^{a}$ Ed. Upper Saddle River, Prentice Hall, 663p.

Zimmerma, D. W. 2006. Two separate effects of variance heterogeneity on the validity and power of significance tests of location. Statistical Methodology, 3: 351-374.

Accepted September 10, 2010

Published December 16, 2010 